\title{
The Influence of Games and Intelligences to Ability in Mathematics for TK-B's Children
}

\author{
Muhiyatul Huliyah
}

Received: 2912017 / Accepted: 2042017 / Published online: 1362017

(c) 2017 Association of Indonesian Islamic Kindergarten Teachers Education Study Program

\begin{abstract}
This article reported the result of research for the influence of games and intelligences to ability in mathematics for TK-B's children. The research was held in TK/RA Daarul Muqimien of Buaranjati village, Sukadiri subdistrict, Tangerang regency. The amount of sample are 40 TK-B's children. The method used was experimental with $2 \times 2$ factorial design. The results of this research are: (1) there was non significant difference to ability in mathematics for TK-B's children who given by Monopoly game and TK-B's children who given by SnakesLadders game; (2) there was non significant difference to ability in mathematics for TK-B's children with high intelligence who given by monopoly game and Snakes-Ladders game; (3) ability in mathematics for TK-B's children with low intelligence who given by Monopoly game lower than children who given by Snakes-Ladders game; (4) there was significant influence of interaction between games and intelligence to ability in mathematics for TK-B's children. Both monopoly game and Snakes-Ladders game could improve the ability in mathematics for TKB's children.
\end{abstract}

Keywords: games, intelligences, TK-B's children, mathematics ability

\begin{abstract}
Abstrak Artikel ini memaparkan hasil penelitian tentang pengaruh permainan game dan inteligensi terhadap kemampuan matematika anak TK-B. Adapun penelitian yang dilakukan merupakan studi eksperimen domain faktorial 2x2 di TK/RA Daarul Muqimien Desa Buaranjati, Kecamatan Sukadiri, Kabupaten Tangerang. Jumlah sampel sebanyak 40 anak TK-B. Hasil penelitian adalah sebagai berikut: (1) Tidak terdapat perbedaan yang signifikan pada kemampuan matematika anak TK-B yang diberikan permainan game monopoli dan anak yang diberikan permainan game ular tangga. (2) Bagi anak yang memiliki inteligensi tinggi, kemampuan matematika anak TK-B antara anak yang diberikan permainan game monopoli tidak berbeda nyata dengan anak yang diberikan permainan game ular tangga. (3) Bagi anak yang memiliki inteligensi rendah, kemampuan matematika anak TK-B antara anak yang diberikan permainan game monopoli lebih rendah daripada anak yang diberikan permainan game ular tangga. (4) Terdapat pengaruh interaksi yang signifikan antara permainan game monopoli dan game ular tangga serta inteligensi terhadap kemampuan matematika anak TK-B. Permainan game monopoli dan ular tangga dapat digunakan untuk meningkatkan kemampuan matematika anak TK-B.
\end{abstract}

Kata kunci: game, inteligensi, anak TK-B, kemampuan matematika 


\section{Pendahuluan}

Matematika dapat ditemukan dalam kehidupan sehari-hari dan dijadikan sebagai salah satu mata pelajaran wajib serta sudah mulai diperkenalkan di Taman Kanak-kanak. Matematika bukan hanya berhitung, tetapi berhitung pasti matematika, karena berhitung bagian dari matematika. Matematika (mungkin) tidak mudah, karenanya sering ditakuti anak-anak. Matematika dianggap pelajaran yang menakutkan, membosankan dan tidak terlalu berguna dalam kehidupan seharihari. Ketakutan itu muncul diduga karena anak sudah diprakondisikan oleh orangtua bahkan lingkungan. Padahal manfaat matematika tak sebanding dengan predikat atau stigma buruknya. Mempelajari matematika dapat mengembangkan kemampuan berpikir analitis, daya ingat, rasio dan logika. Matematika juga dapat menyeimbangkan kemampuan kedua belahan otak. Otak kiri yang mengatur berpikir analistis, logis, dan penyimpanan ingatan, harus bersinergi dengan otak kanan yang mengatur berpikir imajinatif, kreatif dan holistik (Ellys, 2006: 166).

Pembelajaran matematika di sekolah masih banyak didominasi oleh guru. Penggunaan metode, sarana pembelajaran masih bersifat konvensional sehingga anak tidak aktif, keterampilan berproses anak kurang, akibatnya hasil belajar rendah. Dalam proses pembelajaran, anak kurang didorong mengembangkan kemampuan berpikir. Proses pembelajaran di dalam kelas diarahkan kepada kemampuan anak untuk menghafal informasi, otak anak dipaksa untuk mengingat dan menimbun berbagai informasi tanpa dituntut untuk memahami informasi yang diingatnya itu untuk menghubungkannya dengan kehidupan sehari-hari (Sanjaya: 2008). Akibatnya ketika anak didik kita lulus dari sekolah, mereka pintar secara teoretis, tetapi mereka miskin aplikasi. Pembelajaran matematika lebih menekankan hafalan daripada pengertian, menekankan bagaimana sesuatu itu dihitung bukan mengapa sesuatu itu dihitungnya demikian, lebih mengutamakan kepada melatih otak bukan kegunaan, bahasa/istilah dan simbol yang digunakan tidak jelas, urutan operasi harus diterima tanpa alasan, dan lain sebagainya.

Pembelajaran pada anak usia dini harus sesuai dengan paradigma proses pembelajaran anak usia dini, yaitu belajar sambil bermain. Undang-Undang Republik Indonesia Nomor 23 tahun 2002 tentang perlindungan anak, pasal 11 menyatakan: "Setiap anak berhak untuk istirahat dan memanfaatkan waktu luang, bergaul dengan teman sebaya, bermain, berekreasi, dan berkreasi sesuai dengan minat, bakat, dan tingkat kecerdasan demi pengembangan diri." Isi sebagian UU tersebut jelas menjamin setiap anak untuk memiliki hak penuh dalam menentukan jenis mainan atau permainan yang mereka senangi. Namun kebanyakan orang tua (secara tak sengaja) bahkan mendorong anak memilih permainan yang tidak menunjang proses tumbuh kembangnya (Ellys: 2006). Antara lain dengan membelikan mainan yang praktis dan tidak merangsang kreativitas atau memberikan permainan yang bersifat soliter, yang memenjarakan di rumah, sehingga kehilangan kesempatan melatih fisik mengasah emosi di lingkungan yang tepat. Bermain selain dapat mengembangkan potensi anak juga memudahkan guru dalam upaya pencapaian pembelajaran.

Ruang lingkup penelitian dibatasi pada pengaruh permainan monopoli dan ular tangga serta inteligensi terhadap kemampuan bilangan, penjumlahan dan pengurangan anak TK-B di Taman Kanak-Kanak Islam/Raudhatul Athfal (RA) Daarul Muqimien, desa Buaranjati, kecamatan Sukadiri, kabupaten Tangerang. Dengan penelitian ini, diharapkan dapat digali manfaat permainan monopoli dan ular tangga sehingga diperoleh suatu cara yang mampu mengajarkan berhitung pada anak. Harapannya adalah agar pembelajaran matematika tidak monoton, tidak menakutkan, dan lebih aplikatif, serta dapat memberikan pemahaman yang objektif tentang peningkatan kemampuan matematika anak TK-B melalui permainan monopoli 
dan ular tangga. Manfaat teoretisnya adalah memberikan kontribusi bagi pengembangan ilmu pengetahuan khususnya dalam pembelajaran matematika untuk pokok bahasan bilangan, penjumlahan, dan pengurangan anak TK-B.

\section{Hakikat Kemampuan Matematika Anak TK-B}

Kemampuan sebagai hasil belajar (learning out come) terbagi atas lima kategori, yaitu: (1) kemahiran intelektual (intelectual skills), (2) Informasi verbal (verbal information), (3) Strategi kognitif (cognitive strategies), (4) Keterampilan motorik (motor skills), dan (5) Sikap (attitudes) (Gagne \& Briggs: 1999). Pendapat lain diungkapkan Greenberg \& Baron (1995) bahwa kemampuan merupakan kapasitas mental dan fisik untuk mengerjakan berbagai tugas. Seseorang melakukan tugas dengan kemampuan yang ia miliki. Dengan kapasitas mental yang berupa intelektual ia dapat menyusun kerangka berpikir dalam meyelesaikan tugas yang kemudian ia lakukan dengan fisik. Dengan demikian dapat disimpulkan bahwa kemampuan merupakan perilaku rasional, kekuatan dan kecakapan sebagai hasil pengalamannya dalam kegiatan belajar yang kemudian dilakukan secara fisik.

National Council of Teachers of Mathematics (NCTM) mendiskripsikan prinsip dasar dan standar untuk matematika pada level grade yang berbeda. Untuk Taman Kanak-kanak sampai dengan Grade 2 anak-anak sudah memiliki pemahaman substansial terhadap angka-angka sebelum mereka masuk ke grade satu. Selanjutnya NCTM (2000), memberikan standar pembelajaran matematika untuk grade ini mencakup lima standar isi dan lima standar proses.

Tabel 1.

Standar isi dan standar proses pembelajaran matematika grade 2

(National Council of Teachers of Mathematics: 2000)

\begin{tabular}{|c|c|}
\hline Standar Isi & Standar Proses \\
\hline 1. Penomoran dan operasi & 1. Pemecahan masalah \\
\hline 2. Geometri dan pengertian ruang & 2. Sebab dan bukti \\
\hline 3. Pengukuran & 3. Komunikasi \\
\hline 4. Pola, fungsi, aljabar & 4. Koneksi \\
\hline $\begin{array}{l}\text { 5. Analisis data, statistik, dan kemungkinan } \\
\text { (probability) }\end{array}$ & 5. Representatif (menggambarkan) \\
\hline
\end{tabular}

Ada lima kemampuan matematika yang harus ada dalam program pembelajaran matematika pada pendidikan anak usia dini yaitu: kemampuan berhitung, memahami perbandingan, menguasai perspektif terhadap bentuk, menetapkan konsep waktu, dan berkembangnya kemampuan tentang pengukuran (Santrock: 2007). Pendapat lain disampaikan Suyanto (2005) yang menyatakan bahwa secara umum konsep matematika untuk anak usia dini meliputi: (1) memilih, membandingkan, dan mengurutkan misalnya berdasarkan ukuran dari yang terpendek sampai yang terpanjang; (2) klasifikasi, yaitu mengelompokkan benda-benda ke dalam beberapa kelompok, misalnya berdasarkan bentuknya; (3) menghitung, yaitu menghubungkan antara benda dengan konsep bilangan; (4) angka, sebagai simbol kuantitas; (5) pengukuran, mengukur suatu benda dengan berbagai cara dimulai dari ukuran non-standar menuju ukuran standar; (6) geometri, mengenal bentuk, luas, volume dan area; (7) membuat 
grafik, dengan cara mengenalkan sumbu datar (x) dan tegak (y); (8) membentuk pola; dan (9) problem solving, yaitu kemampuan memecahkan masalah sederhana yang melibatkan bilangan dan operasi bilangan.

Berdasarkan berbagai definisi di atas, dalam artikel ini kemampuan berhitung didefinisikan sebagai perilaku rasional dan kecakapan yang dimiliki individu dalam berhitung menyangkut konsep bilangan dan hitung-hitungan meliputi penjumlahan dan pengurangan, sebagai hasil pengalamannya dalam kegiatan belajar. Kegiatan belajar dilakukan dengan cara eksperimen diberikan perlakuaan dengan menggunakan permainan ular tangga.

\section{Hakikat Permainan Monopoli dan Ular Tangga}

Ada beberapa kriteria yang digunakan oleh banyak pengamat dalam mendefinisikan permainan (Mansur: 2005). Pertama, permainan merupakan sesuatu yang menggembirakan dan menyenangkan. Kedua, permainan tidak mempunyai tujuan ekstrinsik, motivasi anak subjektif dan tidak mempunyai tujuan praktis. Ketiga, permainan merupakan hal yang spontan dan sukarela, dipilih secara bebas oleh pemain. Keempat, permainan mencakup keterlibatan aktif dari pemain. Adapun yang di maksud games adalah kegiatan-kegiatan yang dilakukan untuk memperoleh kenikmatan yang melibatkan aturan dan seringkali kompetisi dengan satu atau lebih orang. Menurut Bettelheim dalam Suryadi (2007), kegiatan ini ditandai oleh aturan dan persyaratan yang disetujui bersama dan ditentukan dari luar untuk menggunakan kegiatan dalam tindakan yang bertujuan.

Pendapat lain di sampaikan oleh Bettelheirn dalam Tedjasaputra (2001) yang mengemukakan bahwa permainan adalah kegiatan yang ditandai aturan serta persyaratanpersyaratan yang disetujui bersama dan ditentukan dari luar untuk melakukan kegiatan dalam tindakan yang bertujuan. Aturan maupun persyaratan yang dibuat berdasarkan kesepakatan bersama. Dengan demikian permainan adalah aktivitas yang menyenangkan, tanpa paksaan, semata-mata untuk aktivitas sendiri, bukan untuk memperoleh sesuatu yang dihasilkan dari aktivitas itu. Kaitannya dengan pembelajaran penjumlahan dan pengurangan, permainan harus melibatkan aktivitas kognitif dari tingkat sederhana ke tingkat yang lebih kompleks, seperti menyebutkan angka, menjumlahkan, terus bertahap hingga pengurangan dan lain-lain.

Menurut Sudono et al (2007), sejak usia tiga tahun, minat anak terhadap angka umumnya sangat besar. Pada masa anak dalam tahap pra operasional konkrit, pemahaman atau pengertian diperoleh anak dengan bereksplorasi menghitung segala macam benda yang dapat dihitung. Seiring dengan bertambahnya usia dan perkembangan pemahamannya anak mulai memvisualisasikan berbagai konsep, seperti minatnya untuk menulis sendiri tanpa paksaan berupa lambang bilangan, bentuk-bentuk dan lainnya. Kegiatan ini akan lebih menarik dilakukan melalui permainan dengan prinsip-prinsip permainan matematika sebagai berikut.

1. Permainan matematika diberikan secara bertahap diawali dengan eksplorasi menghitung benda-benda atau pengamatan terhadap benda-benda atau pengamatan terhadap alam sekitar terhadap pengalaman peristiwa konkrit yang dialami.

2. Pengetahuan dan keterampilan yang diberikan secara bertahap menurut tingkat kesukarannya, yaitu dari konkrit ke abstrak, mudah ke sukar, sederhana ke yang lebih kompleks.

3. Permainan matematika akan berhasil jika anak-anak dilibatkan atau diberi kesempatan dan dirangsang untuk menyelesaikan masalah-masalahnya sendiri. 
4. Permainan matematika membutuhkan suasana menyenangkan dan memberikan rasa aman serta kebebasan pada anak. Untuk itu diperlukan alat peraga/media yang sesuai dengan tujuan menyenangkan, menantang, bervariasi, mudah digunakan, dan tidak membahayakan.

5. Bahasa yang digunakan di dalam permainan matematika seyogyanya menggunakan bahasa sederhana dan jika memungkinkan mengambil contoh yang terdapat di lingkungan sekitar anak.

6. Tidak semua anak mengalami perkembangan yang sama. Untuk itu, permainan matematika seharusnya diberikan tidak secara klasikal dan anak-anak dapat dikelompokkan sesuai dengan tahapan penguasaan berhitungnya yaitu tahap konsep, transisi, dan lambang.

7. Evaluasi terhadap kemampuan anak dalam permainan matematika haruslah secara keseluruhan mulai dari awal sampai akhir kegiatan termasuk proses dan tidak hanya menekankan pada hasil produk.

Adapun permainan yang dimaksud dalam artikel ini adalah kegiatan yang dilakukan untuk mendapatkan kenikmatan yang dilakukan oleh dua atau lebih yang memiliki peraturan tertentu yang disepakati bersama para pemain dan bersifat kompetisi. Permainan yang digunakan adalah monopoli dan ular tangga.

Game monopoli adalah salah satu permainan papan yang paling terkenal di dunia. Dalam permainan ini, pemain berlomba untuk mengumpulkan kekayaan melalui pelaksanaan sistem ekonomi mainan yang melibatkan pembelian, penyewaan dan pertukaran tanah dengan menggunakan uang mainan. Pemain mengambil giliran untuk melemparkan dadu dan bergerak di sekeliling papan permainan mengikuti bilangan yang diperoleh dengan lemparan dadu tadi.

Tujuan game monopoli adalah untuk menguasai semua petak di atas papan melalui pembelian, penyewaan dan pertukaran properti dalam sistem ekonomi yang sederhana. Setiap pemain melemparkan dadu secara bergiliran untuk memindahkan bidaknya, dan apabila ia mendarat di petak yang belum dimiliki oleh pemain lain, ia dapat membeli petak itu sesuai harga yang tertera. Bila petak itu sudah dibeli pemain lain, ia harus membayar pemain itu uang sewa yang jumlahnya juga sudah ditetapkan. Ringkasnya, para pemain dengan uang mainan yang sebelumnya telah dibagi rata sesama pemain dapat membeli dan menyewakan properti, membayar biaya perawatan dan menghindari "penjara" ketika mereka berpindah pada papan permainan.

Peralatan yang dibutuhkan untuk memainkan game monopoli yaitu:

1. Bidak-bidak untuk mewakili pemain. Disediakan 10 bidak yaitu topi, setrika, anjing, kapal perang, mobil, gerobak, gelas, meriam, kuda dan sepatu.

2. Dua buah dadu bersisi enam.

3. Kartu hak milik untuk setiap properti. Kartu ini diberikan kepada pemain yang membeli properti itu. Di atas kartu tertera harga properti, harga sewa, harga gadai, harga rumah dan hotel.

4. Uang-uangan game monopoli (Gambar 1).

5. Papan permainan dengan petak-petak (Gambar 2)

a. 22 tempat, dibagi menjadi delapan kelompok berwarna dengan masing-masing dua atau tiga tempat. Seorang pemain harus menguasai satu kelompok warna sebelum ia boleh membeli rumah atau hotel.

b. Empat stasiun kereta. Pemain memperoleh sewa lebih tinggi bila ia memiliki lebih dari satu stasiun. Tetapi di atas stasiun tidak boleh dibangun rumah atau hotel. 
c. Dua perusahaan, yaitu perusahaan listrik dan perusahaan air. Pemain memperoleh sewa lebih tinggi bila ia memiliki keduanya. Rumah dan hotel tidak boleh dibangun di atas perusahaan.

d. Petak-petak Dana Umum dan Kesempatan. Pemain yang mendarat di atas petak ini harus mengambil satu kartu dan menjalankan perintah di atasnya.

6. Ada 32 rumah dan 12 hotel dari kayu atau plastik. Rumah biasanya berwarna hijau, sedangkan hotel berwarna merah.

7. Kartu-kartu Dana Umum dan Kesempatan.

Gambar 1.

Contoh Uang-uangan Game Monopoli

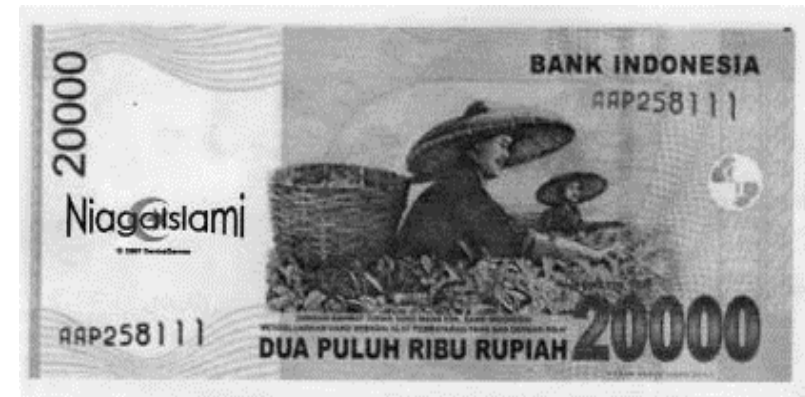

Gambar 2.

Contoh Bentuk Papan Game Monopoli

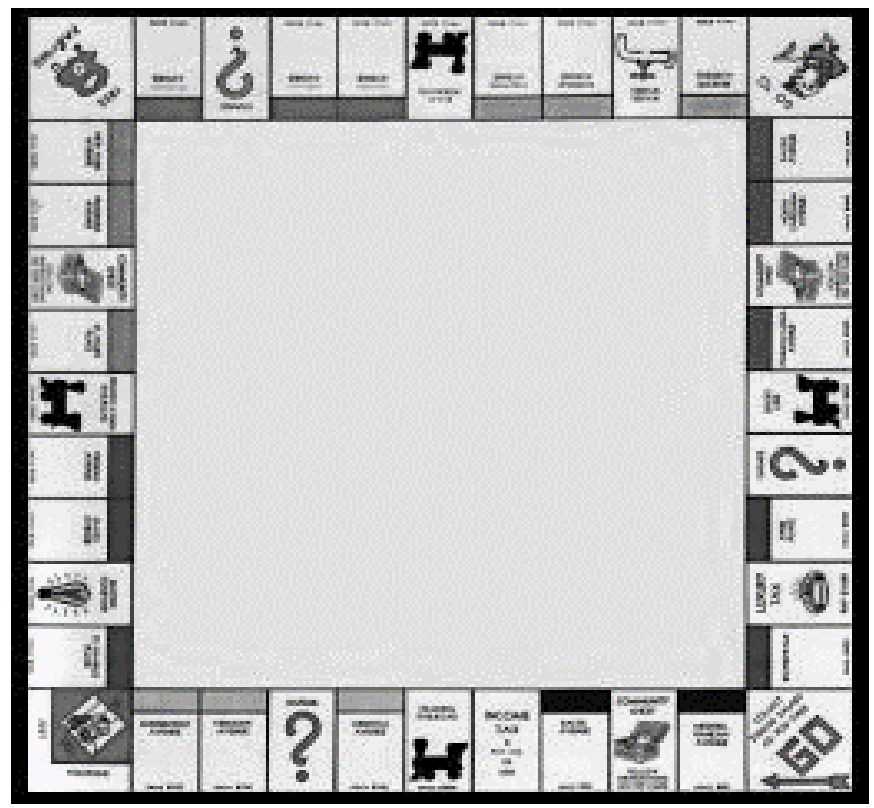

Game ular tangga dapat dimainkan oleh 2-4 orang dengan menggunakan bidak dan dadu untuk mencapai finish dengan melewati hambatan ular dan bantuan tangga. Permainan ini untuk melatih kemampuan logika, semangat kompetisi dan kebersamaan anak (http://www.ceriacerdas.com). Beberapa manfaat permainan ular tangga adalah: (1) Kognitif, kemampuan mengetahui dan mengingat. (2) Motorik, kemampuan mengkoordinasikan anggota tubuh seperti tangan dan kaki. (3) Logika, kemampuan berpikir secara tepat dan teratur. (4) 
Emosional/sosial, kemampuan merasakan dan menjalin hubungan interpersonal. (5) Visual, kemampuan mata menangkap bentuk dan warna obyek (Internet, Elliott Avedon Museum dan Arsip dari Game University of Waterloo University of Waterloo 200 University Avenue West 200 University Avenue Barat Waterloo, Ontario, Canada N2L 3G1 Waterloo, Ontario, Kanada). Adapun cara memainkan game ular tangga yaitu :

1. Siapkan papan permainan (Gambar 3), bidak dan dadu.

2. Pilih bidak yang diinginkan untuk masing-masing pemain (2-4 anak).

3. Pemain yang mendapat giliran pertama adalah pemain yang mendapat angka dadu paling besar. Pemain berikutnya sesuai dengan urutan angka dadu yang diperoleh.

4. Mulailah permainan dengan cara melempar dadu dan melangkahlah sesuai dengan angka dadu yang diperoleh, secara bergantian.

5. Apabila berhenti di kotak yang ada tangganya, maka pemain dapat naik ke kotak sampai di ujung tangga. Namun apabila pemain berhenti di kotak yang ada ularnya maka dia harus turun sampai kotak di ekor ular.

6. Pemenangnya adalah pemain yang sampai di kotak finish paling awal.

Gambar 3.

Contoh Bentuk Papan Permainan Ular Tangga

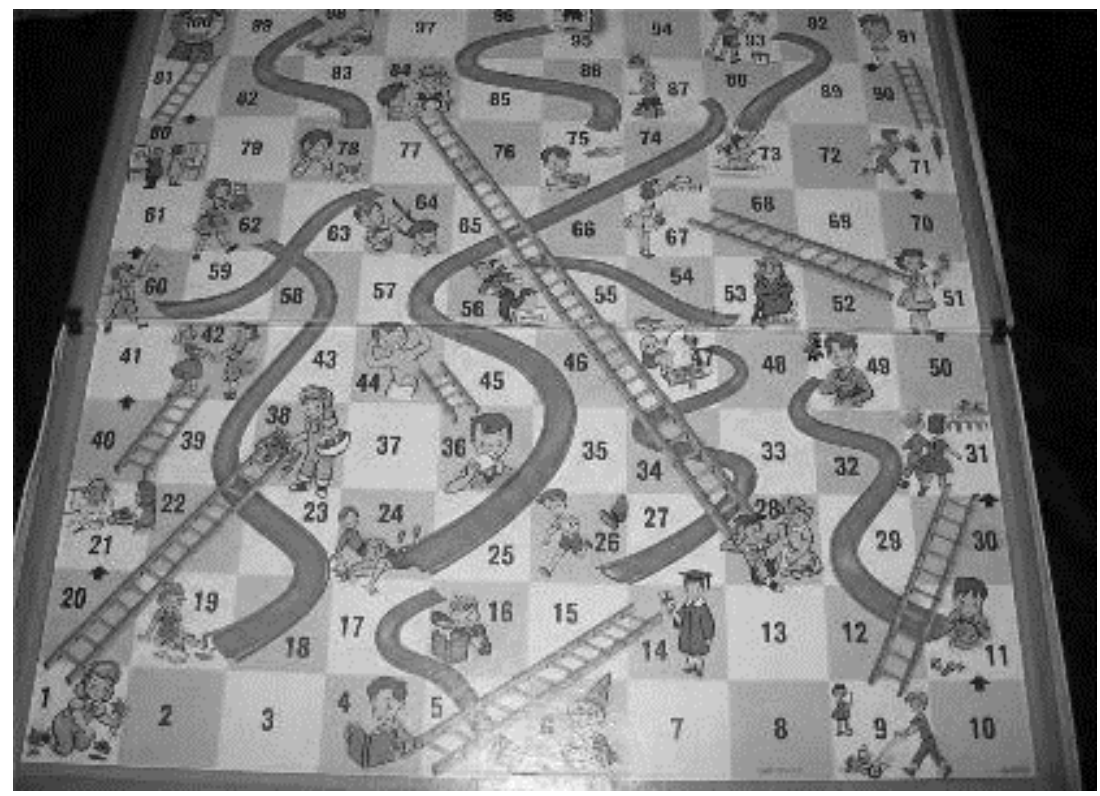

\section{Tes Inteligensi}

Tes inteligensi pada penelitian ini dilakukan oleh psikolog dengan menggunakan Standar Binet. Menurut Santoso (2004), ukuran tingkat inteligensi (Intelligence Quotient) digolongkan menjadi sembilan, yaitu:

Di atas 140 : luar biasa, genius

$120-139$ : cerdas sekali, very superior

$110-119$ : cerdas, superior

90-109 : sedang, Average

80-89 : bodoh, Dull Average 
$70-79 \quad$ : anak pada batas, Border Line

50-69 : debil, Moron

30-49 : ambisil, Embicile

Di bawah 30 : idiot

Gambar 4.

Kurva Nilai Inteligensi

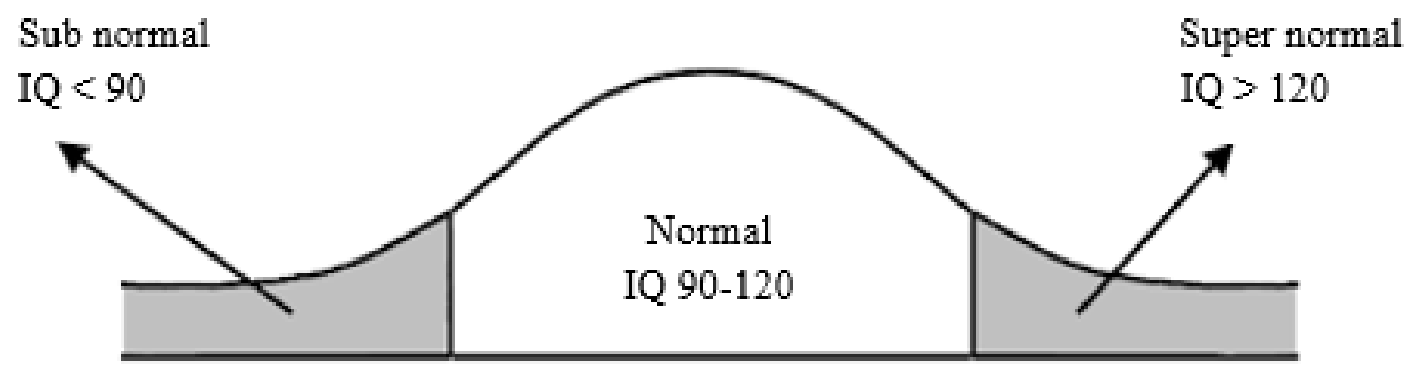

\section{Metode dan Desain Penelitian}

Penelitian ini merupakan penelitian eksperimen. Penelitian ini berupaya menjelaskan kemampuan matematika anak TK-B. Dengan variabel terikat kemampuan matematika anak TKB pokok bahasan bilangan, penjumlahan, dan pengurangan, variabel bebas permainan game menggunakan monopoli dan ular tangga, dan variabel atribut inteligensi.

Desain penelitian eksperimen ini menggunakan desain faktorial 2x2 dengan matriks rancangan eksperimen ini yang diadaptasi dari Ary, et al (2004 : 389) dan Suryabrata (1997 : 50 52) sebagaimana diperlihatkan pada Tabel 2.

Tabel 2.

Desain Penelitian

\begin{tabular}{|l|c|c|}
\hline \multicolumn{1}{|c|}{$\begin{array}{c}\text { Permainan Game } \\
\text { Inteligensi }(\mathrm{B})\end{array}$} & $\begin{array}{c}\text { Game Monopoli } \\
\left(\mathrm{A}_{1}\right)\end{array}$ & Game Ular Tangga $\left(\mathrm{A}_{2}\right)$ \\
\hline Tinggi $\left(\mathrm{B}_{1}\right)$ & $\mathrm{A}_{1} \mathrm{~B}_{1}$ & $\mathrm{~A}_{2} \mathrm{~B}_{1}$ \\
\hline Rendah $\left(\mathrm{B}_{2}\right)$ & $\mathrm{A}_{1} \mathrm{~B}_{2}$ & $\mathrm{~A}_{2} \mathrm{~B}_{2}$ \\
\hline
\end{tabular}

Keterangan:

$\mathrm{A}_{1} \quad=$ Kelompok anak yang diberikan permainan game monopoli sebagai kelas eksperimen

$\mathrm{A}_{2} \quad=$ Kelompok anak yang diberikan permainan game ular tangga sebagai kelas kontrol

$\mathrm{B}_{1} \quad=$ Kelompok anak inteligensi tinggi

$\mathrm{B}_{2}=$ Kelompok anak inteligensi rendah

$\mathrm{A}_{1} \mathrm{~B}_{1}=$ Kelompok anak yang diberikan perlakuan permainan game monopoli dan tingkat inteligensi tinggi

$\mathrm{A}_{1} \mathrm{~B}_{2}=$ Kelompok anak yang diberikan perlakuan permainan game monopoli dan tingkat inteligensi rendah 
$\mathrm{A}_{2} \mathrm{~B}_{1}=$ Kelompok anak yang diberikan perlakuan permainan game ular tangga dan tingkat inteligensi tinggi.

$\mathrm{A}_{2} \mathrm{~B}_{2}=$ Kelompok anak yang diberikan perlakuan permainan game ular tangga dan tingkat inteligensi rendah.

Tabel 3.

Komposisi Subjek Penelitian menurut Jenis Perlakuan

\begin{tabular}{|l|c|c|}
\hline \multicolumn{1}{|c|}{$\begin{array}{c}\text { Permainan Game } \\
(\mathrm{A})\end{array}$} & $\begin{array}{c}\text { Game Monopoli } \\
\left(\mathrm{A}_{1}\right)\end{array}$ & Game Ular Tangga $\left(\mathrm{A}_{2}\right)$ \\
Inteligensi $(\mathrm{B})$ & 10 & 10 \\
\hline Tinggi $\left(\mathrm{B}_{1}\right)$ & 10 & 10 \\
\hline Rendah $\left(\mathrm{B}_{2}\right)$ & 20 & 20 \\
\hline Rerata & & \\
\hline
\end{tabular}

Keterangan:

$\mathrm{A}_{1} \quad=$ Kelompok anak yang diberikan permainan game monopoli sebagai kelas eksperimen.

$\mathrm{A}_{2}=$ Kelompok anak yang diberikan permainan game ular tangga sebagai kelas kontrol.

$\mathrm{B}_{1}=$ Inteligensi tinggi

$\mathrm{B}_{2} \quad=$ Inteligensi rendah

\section{Teknik Pengumpulan Data}

Variabel dalam penelitian ini dibedakan atas variabel bebas, variabel atribut, dan variabel terikat. Variabel bebas pada penelitian ini yaitu permainan game monopoli dan ular tangga, adapun variabel atributnya adalah inteligensi anak TK-B yang tinggi dan rendah, sedangkan variabel terikatnya yaitu kemampuan matematika anak TK-B untuk pokok bahasan bilangan, penjumlahan, dan pengurangan. Perlakuan (treatment) dalam penelitian ini terdiri dari tiga aspek yaitu: (1) materi pembelajaran, (2) strategi pembelajaran dan (3) pelaksanaan perlakuan.

Pelaksanaan perlakuan yang diberikan kepada anak secara rinci dapat digambarkan sebagai berikut:

1. pada pertemuan pertama dan kedua anak diberikan materi pembelajaran dengan menggunakan metode, media dan sumber pembelajaran yang sama untuk kedua kelompok

2. pertemuan ketiga dan keempat lanjutan pembelajaran dengan metode, media dan sumber pembelajaran yang sama

3. pertemuan kelima, kedua kelompok diberi perlakuan yang berbeda yaitu kelompok eksperimen diberikan permainan game monopoli dan kelompok kontrol diberikan permainan game ular tangga

4. pertemuan keenam dan selanjutnya kedua kelompok diberikan perlakuan yang berbeda. Kelompok eksperimen diberikan permainan game monopoli dan kelompok kontrol diberikan permainan game ular tangga.

\section{Instrumen Penelitian}

Instrumen dalam penelitian ini adalah mengumpulkan data tentang kemampuan matematika pokok bahasan bilangan, penjumlahan, dan pengurangan dan data inteligensi anak TK-B. 
1. untuk memperoleh data tentang inteligensi peneliti dibantu tenaga ahli yang berkompeten dan sudah mempunyai kewenangan dalam bidang pengukuran tes psikologi. Data tentang inteligensi anak akan diperoleh melalui pengukuran yang menggunakan tes objektif yang dirancang khusus dalam penelitian ini.

2. untuk memperoleh data tentang kemampuan matematika anak TK-B pokok bahasan bilangan, penjumlahan, dan pengurangan digunakan instrumen tes tertulis dalam bentuk uraian dan alternatif jawaban. Instrumen tentang kemampuan matematika disusun oleh peneliti sebanyak 26 butir. Penyebaran butir didasarkan pada dimensi: bilangan, penjumlahan, dan pengurangan yang disintesis dari para ahli dan proporsi materi yang ada pada kurikulum 2006 untuk TK-B khusus pokok bahasan bilangan, penjumlahan, dan pengurangan. Cara pemberian skor pada jawaban anak adalah dengan skala Likert, yaitu memberi skor satu pada jawaban yang benar dan mendapatkan skor nol jika jawaban salah.

Uji coba kesahihan instrumen dilakukan kepada 20 responden di luar sampel yaitu di TK/RA Mathlaul Anwar yang memiliki kemiripan karakteristik karena sama-sama berada di bawah naungan Departemen Agama (Depag) dan masih berada dalam satu wilayah yang sama dengan TK/RA Daarul Muqimien. Kalibrasi yang dilakukan pada instrumen kemampuan matematika anak TK-B adalah penganalisisan butir, meliputi validasi dan reliabilitas. Penelitian ini menggunakan dua kriteria untuk menentukan kevalidan sebuah instrumen yaitu melalui pendekatan validitas isi dan pendekatan validitas konstruk. Validitas isi instrumen dilakukan berdasarkan indikator-indikator yang telah dikemukakan pada definisi konseptual. Sedangkan validitas konstruk dilakukan dengan pendekatan statistik dengan teknik Korelasi Point Biserial. Reliabilitas instrumen pada prinsipnya adalah untuk menguji tingkat keajegan instrumen jika dipakai berkali-kali. Reliabilitas instrumen diuji dengan rumus KR.20 (Kuder Richardson).

\section{Analisis Data}

Sebelum melakukan analisis data, dilakukan uji prasyarat dengan uji normalitas dan uji homogenitas. Uji normalitas dilakukan untuk mengetahui apakah sampel berasal dari populasi yang berdistribusi normal atau tidak. Dalam penelitian ini uji normalitas sampel menggunakan rumus Chi kuadrat. Pengujian hipotesis menggunakan uji ANOVA analisis varian, dengan ringkasan ANOVA homogenitas dilakukan dengan menggunakan rumus dua varians.

\section{Hipotesis Statistik}

Hipotesis statistik yang diuji dalam penelitian ini adalah :

\begin{tabular}{|c|c|}
\hline Hipotesis 1 & $\mathrm{H}_{0}: \mu \mathrm{A}_{1}=\mu \mathrm{A}_{2}$ \\
\hline & $\mathrm{H}_{1}: \mu \mathrm{A}_{1}>\mu \mathrm{A}_{2}$ \\
\hline Hipotesis 2 & $\mathrm{H}_{0}: \mu \mathrm{A}_{1} \mathrm{~B}_{1}=\mu \mathrm{A}_{2} \mathrm{~B}_{1}$ \\
\hline & $\mathrm{H}_{1}: \mu \mathrm{A}_{1} \mathrm{~B}_{1}>\mu \mathrm{A}_{2} \mathrm{~B}_{1}$ \\
\hline Hipotesis 3 & $\mathrm{H}_{0}: \mu \mathrm{A}_{1} \mathrm{~B}_{2}=\mu \mathrm{A}_{2} \mathrm{~B}_{2}$ \\
\hline & $\mathrm{H}_{1:} \mu \mathrm{A}_{1} \mathrm{~B}_{2}<\mu \mathrm{A}_{2} \mathrm{~B}_{2}$ \\
\hline Hipotesis 4 & $\mathrm{H}_{0}:$ INT. $\mathrm{A} \times \mathrm{B}=0$ \\
\hline & $\mathrm{H}_{1:}$ INT. $\mathrm{A} \times \mathrm{B} \neq 0$ \\
\hline
\end{tabular}

Keterangan:

A $\quad=$ Permainan game monopoli

$\mathrm{B}=$ Permainan game ular tangga 


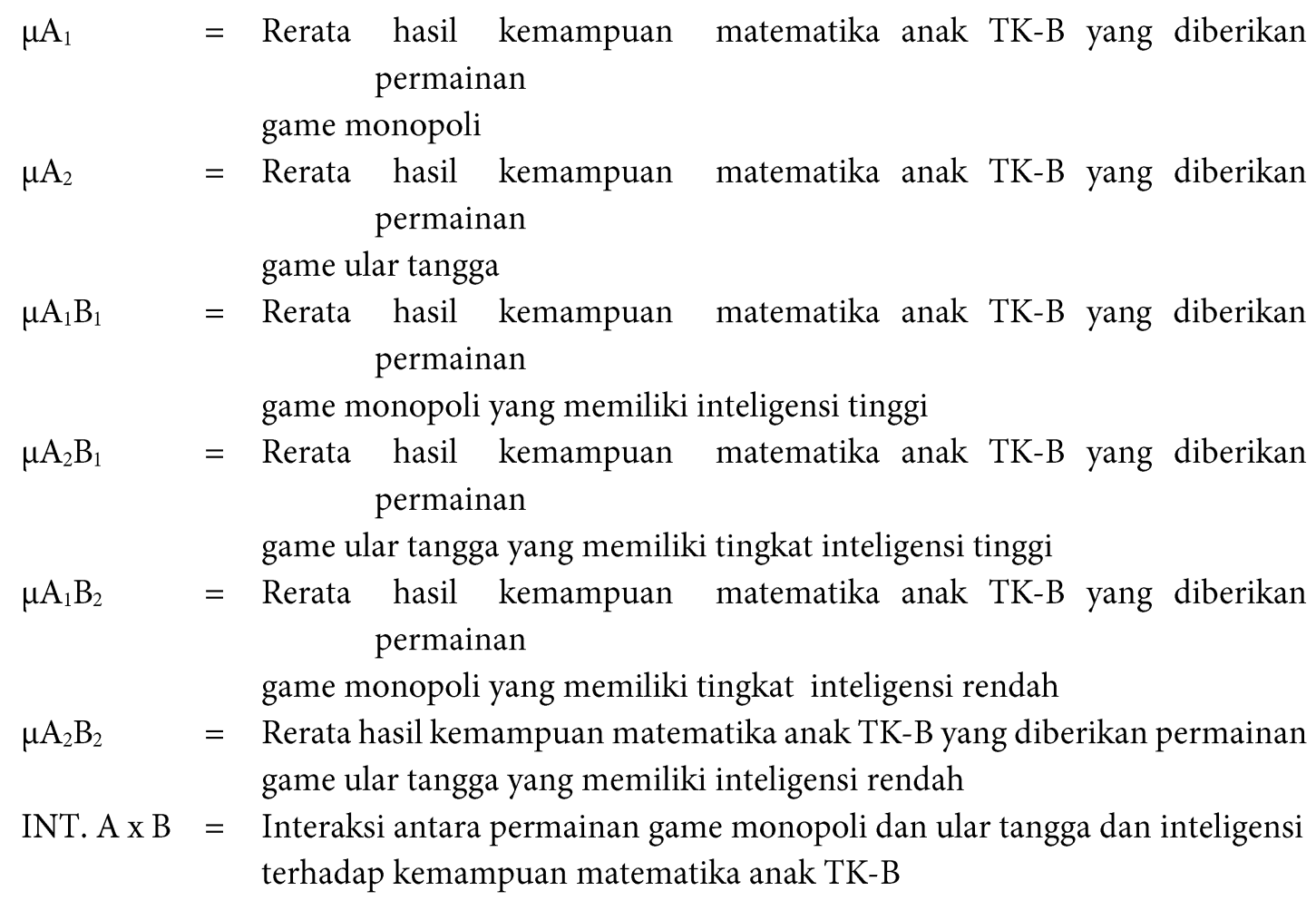

\section{Hasil dan Pembahasan}

Skor kemampuan matematika anak TK-B yang diberikan perlakuan permainan monopoli (A1) dan ular tangga (A2) dengan tingkat inteligensi tinggi (B1) dan rendah (B2), diperlihatkan pada Tabel 4. Sedangkan hasil analisis data dengan analisis varians dua jalan pada hipotesis penelitian pertama diperlihatkan pada Tabel 5 .

1. Perbedaan kemampuan matematika anak TK-B, antara anak yang diberikan permainan game monopoli dan anak yang diberikan permainan game ular tangga.

Hipotesis penelitian pertama yaitu: "Terdapat perbedaan yang signifikan pada kemampuan matematika anak TK-B yang diberikan permainan game monopoli dan anak yang diberikan permainan game ular tangga." Hipotesis ini mengandung makna bahwa kemampuan matematika anak TK-B antara anak yang diberikan permainan game monopoli lebih tinggi dengan anak yang diberikan permainan game ular tangga.

Tabel 4.

Skor kemampuan matematika anak TK-B

\begin{tabular}{|c|c|c|c|c|c|}
\hline \multirow{2}{*}{$\begin{array}{l}\text { Inteligensi } \\
\text { (B) }\end{array}$} & \multicolumn{4}{|c|}{ Perlakuan Permainan (A) } & \multirow{2}{*}{ Jumlah B } \\
\hline & $A_{1}$ & onopoli) & $\mathrm{A}_{2}(\mathrm{U}$ & Tangga) & \\
\hline \multirow{5}{*}{$\mathrm{B}_{1}$ (Tinggi) } & 20 & 16 & 10 & 19 & \multirow{5}{*}{20} \\
\hline & 24 & 23 & 24 & 21 & \\
\hline & 20 & 24 & 23 & 15 & \\
\hline & 24 & 24 & 21 & 22 & \\
\hline & 17 & 24 & 22 & 24 & \\
\hline
\end{tabular}




\begin{tabular}{|c|rr|rr|l|}
\hline & 9 & 16 & 20 & 13 & \\
B $_{2}$ (Rendah) & 7 & 10 & 24 & 8 & \multirow{2}{20}{} \\
& 18 & 9 & 10 & 14 & \\
& 9 & 12 & 17 & 21 & \\
& 11 & 9 & 24 & 24 & $\mathbf{4 0}$ \\
\hline Jumlah A & & $\mathbf{2 0}$ & & $\mathbf{2 0}$ & \\
\hline
\end{tabular}

Tabel 5.

Hasil analisis varians kemampuan matematika anak TK-B (game monopoli dan ular tangga)

\begin{tabular}{|l|r|r|r|r|r|r|}
\hline \multicolumn{1}{|c|}{$\begin{array}{c}\text { Sumber } \\
\text { Varians }\end{array}$} & \multicolumn{1}{c|}{ JK } & db & \multirow{2}{*}{ RJK } & \multicolumn{2}{c|}{ Fhit } & \multicolumn{2}{c|}{ Ftab } \\
\cline { 5 - 7 } & & & & & 0,05 & 0,01 \\
\hline Antar A & 62,500 & 1 & 62,500 & 3,224 & 4,11 & 7,39 \\
\hline Antar B & 435,600 & 1 & 435,600 & 22,473 & & \\
\hline Interaksi AB & 160,000 & 1 & 160,000 & 8,255 & & \\
\hline Dalam & 697,800 & 36 & 19,383 & & & \\
\hline Total & 1355,900 & 39 & 34,767 & & & \\
\hline
\end{tabular}

Hasil analisis (Tabel 5) menunjukkan bahwa $\mathrm{F}_{\text {hitung }}$ sebesar 3,224 dan nilai $\mathrm{F}_{\text {tabel }}$ pada taraf signifikansi 0,05 sebesar 4,11 dan 0,01 sebesar 7,39. Berarti $F_{\text {hitung }}<F_{\text {tabel, }}$ sehingga $H_{0}$ diterima dan $\mathrm{H}_{1}$ ditolak, sehingga dapat dinyatakan bahwa tidak terdapat perbedaan yang signifikan pada kemampuan matematika anak TK-B antara anak yang diberikan permainan game monopoli dan anak yang diberikan permainan game ular tangga. Artinya, kemampuan matematika anak TK-B antara anak yang diberikan permainan game monopoli tidak berbeda nyata dengan anak yang diberikan permainan game ular tangga.

Anak TK-B yang diberikan permainan game monopoli, rerata kemampuan matematikanya sebesar 16,30 sedangkan anak TK-B yang diberikan permainan game ular tangga, rerata kemampuan matematikanya sebesar 18,80 sehingga dapat dinyatakan bahwa rerata kemampuan matematika anak TK-B yang menggunakan permainan game monopoli lebih rendah daripada rerata kemampuan matematika anak TK-B yang menggunakan permainan game ular tangga.

2. Perbedaan kemampuan matematika anak TK-B antara anak yang diberikan permainan game monopoli dan anak yang diberikan permainan game ular tangga yang mempunyai inteligensi tinggi.

Hipotesis penelitian kedua yaitu: "Terdapat perbedaan yang signifikan pada kemampuan matematika anak TK-B antara anak yang diberikan permainan game monopoli dan anak yang diberikan permainan game ular tangga yang mempunyai inteligensi tinggi." Bagi anak yang memiliki inteligensi tinggi, kemampuan matematika anak TK-B antara anak yang diberikan permainan game monopoli lebih tinggi daripada anak yang diberikan permainan game ular tangga.

Kelompok anak dengan inteligensi tinggi yang diberikan permainan game monopoli memiliki rerata kemampuan matematika sebesar 21,60 sedangkan kelompok anak dengan inteligensi tinggi yang diberikan permainan game ular tangga memiliki rerata 20,10. Hasil analisis varians untuk kelompok anak yang memiliki inteligensi tinggi diperlihatkan pada Tabel 6. 
Tabel 6.

Perbedaan Kemampuan Matematika Anak TK-B yang Mempunyai Inteligensi Tinggi

\begin{tabular}{|l|c|l|c|c|c|}
\hline & \multirow{2}{*}{ Monopoli } & \multirow{2}{*}{ Ular Tangga } & $\mathrm{F}_{\text {hitung }}$ & \multicolumn{2}{|c|}{$\mathrm{F}_{\text {tabel }}$} \\
\cline { 1 - 3 } & & & & $(\alpha=0,05)$ & $(\alpha=0,01)$ \\
\hline Jumlah Kuadrat (Antar A) & 11,250 & 0,763 & 4,41 & 8,28 \\
\hline Jumlah Kuadrat (Dalam) & 14,739 & & & \\
\cline { 1 - 2 } Derajat Kebebasan $(\mathrm{db})$ & $\mathrm{db}(\mathrm{A})=1 \mathrm{dan} \mathrm{db}(\mathrm{D})=18$ & & & \\
\hline
\end{tabular}

Untuk mengetahui keberartian perbedaan kemampuan matematika anak TK-B, dilakukan analisis menggunakan uji $F$. Hasil perhitungan menunjukkan harga $F_{\text {hitung }}$ sebesar 0,763 sedangkan $F_{\text {tabel }}$ pada taraf signifikansi $\alpha=0,05$ sebesar 4,41 dan pada $\alpha=0,01$ sebesar 8,28 . Hasil perhitungan menunjukkan bahwa $\mathrm{F}_{\text {hitung }}<\mathrm{F}_{\text {tabel, }}$ artinya $\mathrm{H}_{0}$ diterima dan $\mathrm{H}_{1}$ ditolak. Kondisi tersebut menunjukkan bahwa kemampuan matematika anak TK-B pada anak dengan inteligensi tinggi yang diberikan permainan game monopoli tidak berbeda nyata dengan anak inteligensi tinggi yang diberikan permainan game ular tangga.

3. Perbedaan kemampuan matematika anak TK-B antara anak yang diberikan permainan game monopoli dan anak yang diberikan permainan game ular tangga yang mempunyai inteligensi rendah.

Hipotesis penelitian ketiga yaitu: "Terdapat perbedaan yang signifikan pada kemampuan matematika anak TK-B yang diberikan permainan game monopoli dan anak yang diberikan permainan game ular tangga yang mempunyai inteligensi rendah. "Bagi anak yang memiliki inteligensi rendah, kemampuan matematika anak TK-B antara anak yang diberikan permainan game monopoli lebih rendah daripada anak yang diberikan permainan game ular tangga.

Hasil analisis menunjukkan bahwa kelompok anak yang memiliki inteligensi rendah yang diberikan permainan game monopoli memiliki rerata 11,00 sedangkan kelompok anak dengan inteligensi rendah yang diberikan permainan game ular tangga memiliki rerata 17,50 . Hasil analisis varians diperlihatkan pada Tabel 7.

Tabel 7.

Perbedaan Kemampuan Matematika Anak TK-B yang Mempunyai Inteligensi Rendah

\begin{tabular}{|l|c|l|c|c|c|}
\hline & \multirow{2}{*}{ Monopoli } & \multirow{2}{*}{ Ular Tangga } & \multirow{2}{*}{$\mathrm{F}_{\text {hitung }}$} & \multicolumn{2}{|c|}{$\mathrm{F}_{\text {tabel }}$} \\
\cline { 5 - 6 } & & & & $(\alpha=0,05)$ & $(\alpha=0,01)$ \\
\hline Jumlah Kuadrat (Antar A) & 211,250 & 8,792 & 4,41 & 8,28 \\
\hline Jumlah Kuadrat (Dalam) & \multicolumn{2}{|c|}{24,028} & & & \\
\hline Derajat Kebebasan $(\mathrm{db})$ & $\mathrm{db}(\mathrm{A})=1 \mathrm{dan} \mathrm{db}(\mathrm{D})=18$ & & & \\
\hline
\end{tabular}

Hasil perhitungan menunjukkan harga $\mathrm{F}_{\text {hitung }}$ sebesar 8,792 sedangkan $\mathrm{F}_{\text {tabel }}$ pada taraf signifikansi $\alpha=0,05$ adalah 4,41dan $\alpha=0,01$ adalah 8,28. Hal ini menunjukkan bahwa $F_{\text {hitung }}>$ $\mathrm{F}_{\text {tabel }}$ artinya $\mathrm{H}_{0}$ ditolak dan $\mathrm{H}_{1}$ diterima.

Dapat disimpulkan bahwa terdapat perbedaan yang signifikan antara anak yang memiliki inteligensi rendah yang diberikan perlakuan game monopoli dengan anak inteligensi rendah yang 
diberikan perlakuan permainan game ular tangga, di mana anak dengan inteligensi rendah lebih rendah kemampuan matematikanya dengan diberikan perlakuan permainan game monopoli daripada permainan game ular tangga.

4. Pengaruh interaksi antara permainan game yang menggunakan monopoli dan ular tangga serta inteligensi terhadap kemampuan matematika anak TK-B.

Hipotesis penelitian keempat yaitu: "Terdapat pengaruh interaksi antara permainan game monopoli dan game ular tangga serta inteligensi terhadap kemampuan matematika anak TK-B."

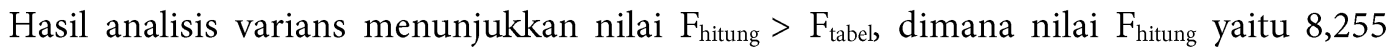
sedangkan nilai $\mathrm{F}_{\text {tabel }}$ pada taraf $\alpha=0,05$ adalah 4,11 . Sehingga dapat dinyatakan bahwa $\mathrm{H}_{0}$ ditolak dan $\mathrm{H}_{1}$ diterima. Berdasarkan hasil analisis uji hipotesis diperoleh kelompok anak dengan inteligensi tinggi yang diberikan perlakuan permainan game monopoli memiliki rerata 21,60 dan kelompok anak dengan inteligensi tinggi yang diberikan perlakuan permainan game ular tangga memiliki rerata 20,10. Sedangkan kelompok anak dengan inteligensi rendah yang diberikan perlakuan permainan game monopoli dan kelompok anak inteligensi rendah yang diberikan perlakuan ular tangga, reratanya masing-masing adalah 11,00 dan 17,50. Hasil analisis tersebut diperlihatkan pada Gambar 5. Hasil analisis varians dua jalan menegaskan adanya interaksi yang signifikan antara permainan game dan inteligensi terhadap kemampuan matematika anak TK-B.

Gambar 5.

Interaksi antara Permainan Game dan Inteligensi terhadap Kemampuan Matematika Anak TKB

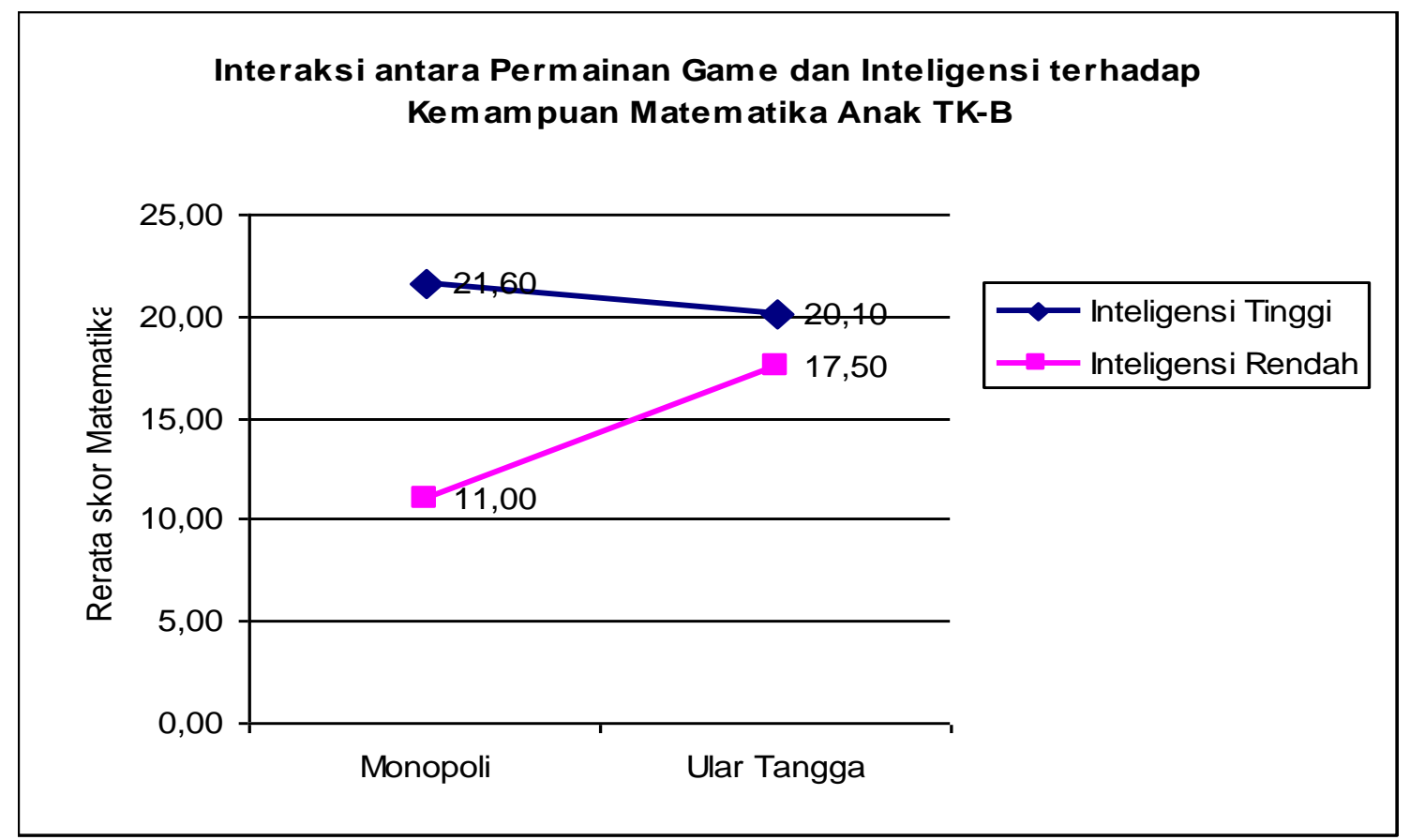

Dua hipotesis yang peneliti ajukan pada penelitian ini ditolak dan dua hipotesis lainnya diterima. Game monopoli dan game ular tangga keduanya dapat dijadikan media pembelajaran matematika anak TK-B, terutama untuk materi berhitung. Dengan bermain game monopoli dan ular tangga anak belajar angka, penjumlahan, pengurangan, perkalian, dan pembagian. Untuk meningkatkan kemampuan matematika anak TK-B, game monopoli dan ular tangga yang 
diberikan pada anak TK-B tidak berbeda nyata, ini berarti kedua game ini dapat meningkatkan kemampuan matematika anak TK-B tetapi hasilnya akan dipengaruhi oleh tingkat inteligensi.

Pada anak dengan inteligensi rendah rerata kemampuan matematika anak yang diberikan perlakuan game monopoli lebih rendah dari rerata anak yang diberikan game ular tangga. Hal ini dimungkinkan karena anak TK-B yang berada pada usia 5 - 6 tahun berada pada masa praoperasional kongkrit memasuki operasional konkrit kurang dapat berpikir abstrak dan baru mulai menggunakan logikanya sehingga kesulitan dalam memainkan game monopoli karena memiliki tingkat kesulitan yang lebih tinggi daripada game ular tangga susah di jangkau oleh anak-anak TK-B terutama yang memiliki inteligensi rendah.

Memberikan kegiatan bermain game monopoli dan ular tangga pada pembelajaran matematika Anak TK-B menjadi lebih efektif. Hal tersebut ditandai dengan proses pembelajaran yang menyenangkan dikarenakan anak TK-B berada pada usia 5 - 6 tahun di mana pada usia tersebut merupakan masa bermain. Anak tidak merasa terbebani menerima materi dalam kondisi yang menyenangkan. Keaktifan dan antusias anak dalam bermain membuat anak memusatkan perhatian pada materi yang diberikan.

Bermain dapat meningkatkan kemampuan anak, tetapi pemilihan media/alat bermain yang kurang tepat memungkinkan tidak akan berpengaruh signifikan terhadap perkembangan kemampuan anak melainkan berbalik dapat merusak atau membahayakan perkembangan anak. Dalam memilih media/alat bermain harus berhati-hati dan disesuaikan dengan karakteristik perkembangan anak. Anak TK-B berusia antara 5 - 6 tahun, ini berarti mereka berada pada tahap akhir pra-operasional konkrit memasuki tahap operasional konkrit. Anak usia empat atau lima tahun mulai menggunakan logikanya dan terus meningkat seiring bertambahnya usia. Permainan yang bernilai kompitisi dapat diberikan pada anak dengan usia ini, dalam upaya meningkatkan kemampuan logikanya. Bentuk kegiatan yang konkrit akan mempermudah anak menerima halhal baru, karena anak usia 5 - 6 kurang mampu berpikir abstrak.

\section{Simpulan}

Berdasarkan pemaparan tersebut di atas, dapat disimpulkan bahwa secara keseluruhan tidak terdapat pengaruh yang signifikan pada kemampuan matematika anak TK-B antara anak yang diberikan permainan game monopoli dan anak yang diberikan permainan game ular tangga. Ini dimungkinkan karena game monopoli dan ular tangga memiliki kemiripan karakteristik cara bermain yaitu melangkah melewati angka-angka berdasarkan lemparan dadu. Bagi anak yang memiliki inteligensi tinggi, kemampuan matematika anak TK-B antara anak yang diberikan permainan game monopoli lebih tinggi daripada anak yang diberikan permainan game ular tangga. Dengan demikian, untuk meningkatkan kemampuan matematika anak TK-B yang memiliki inteligensi tinggi dapat menggunakan game monopoli. Bagi anak yang memiliki inteligensi rendah, kemampuan matematika anak TK-B antara anak yang diberikan permainan game monopoli lebih rendah daripada anak yang diberikan permainan game ular tangga. Anak TK-B dengan inteligensi rendah lebih tinggi kemampuan matematikanya dengan diberikan perlakuan yang menggunakan permainan game ular tangga daripada permainan game monopoli. Terdapat pengaruh interaksi antara permainan game monopoli dan game ular tangga serta inteligensi terhadap kemampuan matematika anak TK-B sehingga kemampuan matematika anak TK-B dapat ditingkatkan dengan permainan game monopoli dan ular tangga. 


\section{Daftar Pustaka}

Ary, Donald, L.C. Jacobs, dan A. Razavish. Introduction to Research in Education (Pengantar Penelitian dalam Pendidikan), diterjamahkan oleh Arief Furchan, Yogyakarta: Pustaka Pelajar, 2004.

Ellys, J. Kiat-kiat Meningkatkan Potensi Belajar Anak, Bandung: Pustaka Hidayah, 2006.

Gagne, Robert M and Lesile J. Briggs. Principles of Instructional Design, New York: Holt, Rikhart and Winston, 1999.

George W.Maxim, The Very Young Guiding Children From Infancy Throught The Early Years, Wadsworth Publishing Company, Inc, 1980.

http://dossuwanda.wordpress.com/artikel/pembelajaran-dengan-model-permainan-monopolypakem.

http://www.komisiyudisial.go.id.

http://www.ceriacerdas.com. [Diunduh tanggal 30-01-2009].

Internet, Elliott Avedon Museum dan Arsip dari Game University of Waterloo University of Waterloo 200 University Avenue West 200 University Avenue Barat Waterloo, Ontario, Canada N2L 3G1 Waterloo, Ontario, Kanada N2L 3G1, download 30-01-2009.

Greenberg, Jerald dan Baron, Robert A. Behavior in Organization, New York: Prentice Hill International, Inc, 1995.

Santrock, John W. Psikologi Pendidikan, Alih Bahasa Tri Wibowo BS., Jilid Kedua Jakarta: Kencana, 2007.

Mansur, Pendidikan Anak Usia Dini dalam Islam, Yogyakarta: Pustaka Pelajar, 2005.

Mayke S. Tedjasaputra, Bermain, Mainan dan Permainan untuk Pendidikan Anak Usia Dini, Jakarta: PT Gramedia, 2001.

Gagne, Robert M dan Briggs, Lesile J. Principles of Instructional Design, Newyork: Holt, Rikhart, and Winston, 1999.

Suyanto, Slamet. Konsep Dasar Pendidikan Anak Usia Dini, Jakarta: Departemen Pendidikan Nasional, 2005.

Santoso, Soegeng. Pendidikan Anak Usia Dini, Jakarta: Citra Pendidikan, 2004.

Sudono, Anggani et al., Permainan Kreatif untuk Anak Usia Dini (Usia 3-7 tahun), Jakarta: Sarana Bobo, 2007.

Suryabrata, Sumadi. Metodologi Penelitian, Jakarta: Raja Grafindo Persada, 1997.

Suryadi, Cara Efektif Memahami Perilaku Anak Usia Dini, Jakarta: Edsa Mahkota, 2007.

Sanjaya, Wina. Strategi Pembelajaran Berorientasi Standar Proses Pendidikan, Jakarta: Kencana Prenada Media Group, 2008. 